\title{
A COVID-19-pandémia mentálhigiénés következményei. Hogyan tudunk felkészülni a pszichodémiás krízisre?
}

\author{
Osváth Péter dr.
}

Pécsi Tudományegyetem, Általános Orvostudományi Kar, Pszichiátriai és Pszichoterápiás Klinika, Pécs

\begin{abstract}
Az elmúlt hónapokban életünket alapvetően megváltoztatta a COVID-19-pandémia, melynek egészségügyi, gazdasági és társadalmi hatásai egyelőre szinte felbecsülhetetlenek. A vírusfertőzés akut következményei mellett egyre több adat bizonyítja a teljes népességre kifejtett hatásait: a pszichológiai distressz, a depressziós és szorongásos tünetek, valamint az addiktív viselkedésformák gyakoriságának növekedését. Az is nagyon fontos kérdés, hogy a globális válsághelyzet hogyan befolyásolja az öngyilkossági arányszámokat. Írásomban az elmúlt időszak legjelentősebb pszichiátriai szakirodalma alapján foglalom össze a vírusfertőzés akut és krónikus hatásait, valamint a járványhelyzet általános és specifikus pszichológiai-pszichopatológiai következményeit, kiemelt figyelmet fordítva a suicidiumrizikóra és a leginkább veszélyeztetett csoportokra. A vizsgálatok arra utalnak, hogy a pandémia következtében kialakuló mentális gondok és a suicid viselkedés egyre fontosabb népegészségügyi problémává válnak. Bár napjainkban még a vírusfertőzöttek gyógyítása és a fertőzés terjedésének lassítása a legfontosabb cél, mindannyiunknak fel kell készülnünk a járvány hosszú távú következményeire. A pandémia várható negatív mentálhigiénés hatásainak megelőzésére és enyhítésére általános és specifikus módszerek kidolgozása és alkalmazása szükséges. Ebben az egészségügyi, mentálhigiénés és közösségi ellátórendszerek mellett szerepet kell vállalniuk a politikai és gazdasági döntéshozóknak, a társadalmi szervezeteknek és a média munkatársainak is. Hatékony együttmúködésük kulcsfontosságú az egyéni, közösségi és társadalmi szinten is alkalmazható prevenciós stratégiák megvalósításában, hiszen csak így válik lehetővé a súlyosabb mentálhigiénés problémák járványszerű elterjedésének, a „pszichodémiának” a megelőzése.

Orv Hetil. 2021; 162(10): 366-374.
\end{abstract}

Kulcsszavak: COVID-19-vírus, lelki egészség, pszichopatológia, öngyilkosság, prevenció

\section{Psychological outcome of COVID-19 pandemic. How can we prepare for a psychodemic crisis?}

In recent months, our lives have been fundamentally changed by the COVID-19 pandemic, the health, economic, and social impacts of which are almost invaluable for the time being. In addition to the acute consequences of viral infection, more and more data are proving its effects on the entire population: an increase in the incidence of psychological distress, depressive and anxiety symptoms, and addictive behaviours. It is also a very important question, how the global crisis is affecting suicide rates. In my paper, I summarize the acute and chronic effects of viral infection and the general and specific psychological-psychopathological consequences of the epidemic based on the most significant psychiatric literature of the recent period, paying special attention to suicidal risk and the most vulnerable groups. Studies suggest that mental troubles and suicidal behaviour resulting from a pandemic are becoming an increasingly important public health problem. Although the treatment of viral infections and slowing the spread of the infection are still the most important goals today, we all need to be prepared for the long-term consequences of the epidemic. In order to prevent and mitigate the expected negative mental health effects of a pandemic, it is necessary to develop and apply general and specific methods. In addition to health care, mental health and community care systems, political and economic decision-makers, civil society organizations and the media must also play a role. Their effective cooperation is key to the implementation of prevention strategies that can be applied at the individual, community and social levels, as this is the only way to prevent the epidemic spread of more serious mental health problems, the "psychodemia".

Keywords: COVID-19 virus, mental health, psychopathology, suicide, prevention

Osváth P. [Psychological outcome of COVID-19 pandemic. How can we prepare for a psychodemic crisis?] Orv Hetil. 2021; 162(10): 366-374.

(Beérkezett: 2020. december 21.; elfogadva: 2021. január 15.) 


\section{Rövidítések}

COVID-19 = (coronavirus disease 2019) koronavírus-betegség 2019; WHO = (World Health Organization) Egészségügyi Világszervezet

Az elmúlt év orvostudományi szakirodalmának legfontosabb témakörét a COVID-19-járvány képezte; az akut és (a várható) hosszú távú egészségügyi következményeivel foglalkozó közlemények sokaságával találkozhatunk, melyek zöme a vírus biológiai-infektológiai hatásaival és kezelési lehetőségeivel foglalkozik. Szerencsére ma már egyre többet olvashatunk a vírusfertőzés idegrendszeri és mentálhigiénés-pszichológiai következményeiről is. A 21. század eddigi legnagyobb hatású, a modern társadalmak életét a legváltozatosabb módon és mértékben befolyásoló világjárvány gazdasági-kulturális-társadalmi hatásai egyelőre szinte felbecsülhetetlenek. Az elmúlt hónapokban a járvány korábban sosem látott sebességgel terjedt el az egész világon, így ezen összefoglaló írásának idején (2020 decemberében) a járvány második hullámának emelkedő szakaszában vagyunk, és még közel sem körvonalazódik a vége, bár a védőoltások alkalmazásának lehetósége óvatos optimizmusra ad okot. A kutatók már a tavaszi időszakban felhívták a figyelmet a járvány akut és elhúzódó pszichológiai és mentálhigiénés hatásaira és a mentális zavarok gyakoriságának várható emelkedésére [1-3]. Az elmúlt hónapokban végzett epidemiológiai felmérések ezt az akkor még talán pesszimistának tûnő előrejelzést maximálisan visszaigazolták, hiszen a pszichológiai distressz, a depressziós és szorongásos tünetek, valamint az addiktív viselkedésformák gyakoriságának növekedését észlelték. A járvány következtében kialakuló megbetegedések ellátása egyre nagyobb kihívás elé állítja a „békeidőben” is túlterhelt egészségügyi ellátórendszereket és más segítő szolgálatokat [2]. Az egyik legfontosabb kérdés az, hogy milyen közvetett és közvetlen hatásokra számíthatunk, és hogyan készülhetünk fel ezek megelőzésére és hatékony kezelésére. Írásomban az elmúlt hónapok legjelentôsebb pszichiátriai szakirodalma alapján szeretném bemutatni a vírusfertőzés és a pandémia akut és elhúzódó pszichológiai-pszichopatológiai következményeit, kiemelt figyelmet fordítva a mentálhigiénés ellátás és a megelőzés lehetőségeire.

\section{A vírusfertőzés akut szövődményei}

Bár a vírusfertőzés pontos patofiziológiáját ma sem ismerjük teljesen, a járvány exponenciálisan emelkedő terjedése miatt egyre többet tudunk a COVID-19-vírus okozta fertőzés szerteágazó tünettanáról és az ezek hátterében álló immunológiai és neurobiológiai változásokról [4]. Jól ismert a vírusfertőzés akut és posztakut (hyperinflammatiós) szakasza, mely sok esetben az immunrendszer súlyos szabályozási zavarát (multiszisztémás gyulladást) idézi elő [5]. Az akutan kialakuló pszichopatológiai szövődmények között a leggyakoribbak az organikus pszichoszindrómák (különböző tudatzavarok, delírium stb.), melyek kórokai között egyre jobban körvonalazódik a vírusfertőzésnek, illetve a következményesen kialakuló gyulladásos és immunológiai mechanizmusoknak a szerepe [6]. A delirózus tudatzavar a hatodik leggyakoribb akut tünet, mely az idős fertőzöttek közel egyharmadánál megjelenik. Ez különösen azokra a multimorbid páciensekre jellemző, akik sokféle gyógyszert (köztük pszichotrop szereket) is szednek. Ezen tudatzavar jelentőségét hangsúlyozza, hogy növeli az intenzív osztályos kezelés időtartamát és a halálozási arányt is [7]. Mivel gyakran ez a fertőzés elsődleges tünete egyéb - a vírusfertőzésre típusos - eltérés nélkül, klinikai szempontból fontos szereppel bír az infekcióhoz társuló delírium jeleinek és típusának felismerése, mivel a különböző megjelenési formák eltérő betegséglefolyással bírnak. Rozzini és mtsai [8] a dementiához társuló hipokinetikus forma esetében észlelték a legmagasabb mortalitást. Így az akut szakaszban megjelenő pszichopatológiai tünetek adekvát értékelése a prognózis előrejelzésében és a páciens kezelésének pontosabb megtervezésében is segítséget nyújt $[7,8]$.

\section{A vírusfertőzés hosszú távú hatásai}

A vírusfertőzés okozta késői (krónikus) gyulladás megjelenési formáinak hátterében is több különféle kórélettani mechanizmust valószínúsítenek. A cardiovascularis és pulmonalis szövődmények mellett neurológiai és pszichológiai következményei is lehetnek [9]. A központi idegrendszeri tünetek hátterében a vírusfertőzés direkt hatásának (encephalitis), a szisztémás gyulladásnak és az ennek következtében kialakuló perifériás funkciózavaroknak (máj, vese, tüdő), valamint a cerebrovascularis változásoknak a komplex interakciója állhat [9]. A krónikus szakasz - más vírusfertőzéshez hasonlóan - sokszor hónapokig is elhúzódhat, és olyan bizonytalan testi tünetekkel járhat, mint például kimerültség, nehezített légzés, ízületi vagy akár mellkasi fájdalmak. Bár ma még elsősorban az akut fertőzés megelőzési és kezelési lehetőségeinek fejlesztése áll a kutatások középpontjában, fel kell készülni arra is, hogy egyre inkább a krónikus formák okozta problémák kerülnek majd előtérbe, ezért nagy jelentőséggel bír a hosszú távú következmények mechanizmusának pontosabb felderítése [4].

$\mathrm{Az}$ idegrendszeri patofiziológiai mechanizmusok természetesen ilyenkor is szövődnek a fertőzéssel kapcsolatos stresszélmény következményeivel, ezek között említhetjük például a fertőzöttséggel kapcsolatos aggodalmakat, a mások megfertőzésétől való félelmet, a tünetek okozta gyötrelmeket, a kórházi (különösen az intenzív osztályos) kezeléssel kapcsolatos korlátozásokat [2]. A súlyos - akár intenzív osztályos kezelést indokló vírusfertőzés túlélői között gyakoribbnak találták a poszttraumás tünetcsoportot is. Tehát a gyógyult betegek esetében jelentős pszichológiai distresszre kell számítani. Janiri és mtsai felmérésében [10] ez a nők és az 
idősebbek körében gyakoribb volt, és pozitívan korrelált az impulzivitással és bizonyos temperamentumjellemzőkkel (például a depressziós vagy a ciklotim típusokkal). Ezen eltérések hátterében az emocionális diszreguláció mediáló szerepét emelik ki. A szerzők az adekvát érzelmi szabályozás szerepét hangsúlyozzák a pszichológiai distressz leküzdésében és így a teljes felépülésben [10]. $\mathrm{Az}$ eddigi legszélesebb körben elvégzett észak-amerikai retrospektív kohorszvizsgálatban a fertőzés túlélői körében a mentális problémák (különösen a szorongásos és depressziós zavarok, a dementia és az insomnia) emelkedett arányát találták, mely folyamatosan növekedett a felgyógyulást követő időszakban. Gyakoriságuk lényegesen meghaladta az influenzán vagy más, felső légúti megbetegedésen átesettek körében észlelt arányszámokat, ez pedig szintén a COVID-19-vírus okozta specifikus neurobiológiai-neuroimmunológiai eltérések etiológiai szerepére hívja fel a figyelmet [11].

Tehát a vírusfertőzés hosszú távú hatásai között olyan pszichológiai-pszichopatológiai maradványtünetek jelentkezhetnek, mint például a szorongásos vagy depreszsziós zavar, valamint a poszttraumás stressz zavar [6]. A pszichológiai distressz és a társuló tünetek indirekt módon járulhatnak hozzá a suicidiumrizikó növekedéséhez a fertőzésből felgyógyultak körében. Kiemelésre érdemes, hogy a legújabb neurobiológiai kutatási eredmények arra utalnak, hogy a vírus bizonyos központi idegrendszeri hatásai (renin-angiotenzin rendszer, gyulladásos faktorok) és az okozott immunológiai diszreguláció direkt és indirekt módon járulhatnak hozzá a suicidiumrizikó emelkedéséhez $[9,12]$. Ráadásul a fertőzés gyógyulását követően sok esetben észlelnek tartós fájdalommal és funkcióromlással járó maradványtüneteket, melyek szintén növelhetik a suicidiumkockázatot [2].

\section{A pandémia általános mentálhigiénés hatásai}

A pandémia következtében kialakuló általános bizonytalanságérzés és fenyegetettség - a fertőzéssel vagy a fertőzöttekkel való közvetlen vagy közvetett érintkezés nélkül is - komoly stresszt okoz a társadalom tagjainak [13]. Ezeket az általános és elhúzódó pszichológiai szövődményeket ma már külön elnevezéssel, a „koronafóbia” névvel illetik. Ez olyan, sajátos alkalmazkodási zavarnak tekinthető, melynek fö tünetei: szédülés, alvászavarok, izomfeszülés, étvágycsökkenés, hányinger és hasi diszkomfort. Nagyon fontos ezeknek a tüneteknek a pontos felmérése annak érdekében, hogy ezt az állapotot el tudjuk különíteni a jól definiálható mentális zavaroktól és a populációra általánosságban jellemző és a helyzetnek megfelelő, de funkcióromlást nem okozó adekvát stresszreakciótól [14].

A járványhelyzet közvetlen pszichoszociális következményeként nagyon gyakori lehet az akut stresszreakció, illetve a krízishelyzet következtében kialakuló szorongás, lehangoltság, kilátástalanság és reménytelenségérzés, az alvászavar vagy akár a suicid gondolatok megjelenése $[5$, 12]. Mivel a járvány még napjainkban is tombol, és hoszszabb távú hatása alig becsülhető meg pontosan, nem könnyű megjósolni azt sem, hogy ez milyen hatással lesz az öngyilkossági gyakoriságra. Bár számos, vírusfertőzéssel összefüggő tragikus öngyilkosságról számoltak be [2], sem a járvány első időszakában végzett epidemiológiai felmérések [15-18], sem a klinikai tapasztalatok nem utalnak a járvánnyal összefüggésben a suicid magatartás gyakoribbá válására. Ez nem meglepő, hiszen a nagy társadalmi tragédiák, például háborúk vagy diktatúrák esetében inkább csökkenni szoktak a suicidiumarányszámok. A korábbi hasonló események utóhatása alapján azonban feltételezhető, hogy a pandémia súlyos gazdasági és mentálhigiénés következményei hosszabb távon növelni fogják az öngyilkos viselkedés előfordulását $[2,12,16,19-23]$.

A pszichés problémák hátterében az általános katasztrófahangulat, az életkörülmények és életfeltételek kedvezőtlen és szokatlan megváltozása, valamint a szociális izoláció mellett kiemelt szerepet játszik a gazdasági válság következtében kialakuló létbizonytalanság és az egzisztenciális helyzet romlásától való félelem is $[2,12,13$, 19, 21-25]. A szociális izoláció és a munkahely elvesztése suicidiumrizikót növelő hatásának hátterében két olyan, jól ismert lélektani jellemző szerepét igazolták, mint az összetartozás hiánya és annak érzése, hogy az egyén terhet jelent mások számára [26].

A gyakran megjelenő alvászavar önmagában is hozzájárul a suicidiumrizikó növekedéséhez, a szorongásos és a depressziós tünetekkel való sajátos kétirányú kapcsolata révén egymás hatását erôsítve súlyosbíthatják az öngyilkossági rizikót [2]. A járványhelyzettel szükségszerúen együtt járó korlátozások a társadalom minden tagjának életét alapvetően megváltoztatják. A negatív hatások között említhetjük például a szociális kapcsolatok beszúkülését [19]. Ez különösen fontos rizikófaktora lehet a suicid viselkedésnek $[2,22]$, mivel a járvány okozta krízishelyzetben a szociális és érzelmi támogatásra különösen nagy szükség lenne. Az izolált helyzet ráadásul az esetlegesen kialakuló suicidiumkrízis jeleinek korai felismerését sem teszi lehetővé.

A kínai felmérések már a járvány kezdetén kimutatták, hogy a populáció közel felénél alakultak ki a járványhelyzet okozta pszichológiai distressz tünetei, míg közel egyharmaduknál közepes vagy súlyos szorongásos, közel egyhatoduknál pedig közepes vagy súlyos depressziós tüneteket észleltek [27]. Más vizsgálatok pedig még magasabb arányokat találtak [28]. A pandémia európai elterjedését követően hasonló arányszámokról számoltak be olasz, spanyol és cseh vizsgálatok is: a populáció közel harmada súlyos stressztünetektől szenvedett, és jelentős növekedést észleltek a szorongásos-depressziós tünetek és a poszttraumás stressz zavar gyakoriságában is [3, 29, 30]. Az Egyesült Államokban tavasszal végzett reprezentatív felmérések is a pszichológiai distressz és a szorongásos-depressziós tünetek növekvő gyakoriságát igazolták 
[31], egyenes arányban a vírusfertőzés terjedésével [32]. A szintén még a járvány tavaszi idôszakában végzett észak-amerikai populációs felmérés a depressziós tünetek több mint háromszoros emelkedését mutatta a járványt megelőző időszakhoz képest (27,8\% vs. 8,5\%) [33]. Egy júliusi vizsgálat még magasabb arányszámokat mutatott az Egyesült Államokban, nemcsak a mentális zavarok, de a szerhasználat és a suicid gondolatok vonatkozásában is. Ezen eredmények szerint a depresszió négyszer, a szorongás háromszor volt gyakoribb, mint a megelőző évben, a suicid gondolatok aránya pedig a kétszeresére nőtt [34]. Kiemelésre érdemes, hogy a depressziós tünettan különösen az alacsony jövedelmú, hátrányos helyzetú, aktuális veszteséget (például állásvesztést) elszenvedett embereket érintette $[28,33]$. A pszichológiai distressz hátterében a leggyakrabban a vírusfertőzés miatti aggodalom $(65,9 \%)$, a munkahely elvesztésétől való félelem $(65,1 \%)$ és az anyagi gondok $(60,6 \%)$ szerepeltek. Ezek az aggodalmak a fiatal felnőttek negyedét érintették, és az is kiderült, hogy a mintában szereplők $35 \%$-a nem kapott megfelelő egészségügyi ellátást a panaszai miatt [34]. Bár a bizonytalanságtól való félelem és szorongás szinte általános tünetnek tekinthető, a sérülékeny egyénekben ez jelentősen megnövelheti a poszttraumás stressz zavar rizikóját, így közvetve is hozzájárulhat a suicid viselkedéshez. Kiemelendő, hogy a járvány okozta korlátozások és pszichés szövődmények következtében gyakoribbá válhatnak a különböző addiktív viselkedésformák is, mint például az alkohol- és drogfüggőség, ami szintén hozzájárulhat az emelkedő öngyilkossági arányszámokhoz $[2,22]$.

\section{A kedvezőtlen hatások által különösen veszélyeztetett csoportok}

Nagyon fontos hangsúlyozni, hogy a pandémia negatív hatásai különböző mértékben hatnak a populáció tagjaira. Az eddigi kutatások alapján számos olyan rizikócsoport azonosítható, akiknél a pandémia közvetlen és közvetett következményei különösen negatívan befolyásolhatják a mentális egészséget, és növelhetik a suicid viselkedés gyakoriságát $[22,24]$. A megelőzés hatékonyságának növeléséért nagyon fontos ezeknek a rizikócsoportoknak az azonosítása és a válság hatásának pontosabb vizsgálata, annak érdekében, hogy célzott és az egyes rizikócsoportok sajátosságaihoz illesztett prevenciós és terápiás beavatkozásokat tudjunk kialakítani [22].

A veszélyeztetett csoportok között elsóként a mentális zavarban szenvedöket kell megemlíteni [13], hiszen őket különösen kedvezőtlenül érintik a korlátozások, a szociális izoláció, valamint a gazdasági és a munkaerópiaci helyzet romlása $[20,35,36]$. Az izoláció és a szociális visszahúzódás - az önpusztításra hajlamosító tüneteket (például szorongás, depresszió vagy alvászavar) provokáló direkt hatás mellett $[32,37]-$ az alapbetegség relapsusán keresztül indirekt módon is növelheti az öngyilkossági rizikót [22]. A mentális zavarokban szenvedók sokkal veszélyeztetettebbek a megfertőződés szempontjából, körükben - a betegség típusától függetlenül - a vírusfertőzés rizikója több mint másfélszeresére nőtt [11]. Ez az eredmény a mentális zavarokkal összefüggő immunológiai tényezőkre, a hátrányos szocioökonómiai helyzetre és bizonyos viselkedési problémákra irányítja a figyelmet, melyek a pszichiátriai betegek csoportjában jelentősen megnehezítik a járvány elleni védekezést [11]. A vírusfertőzés közvetlen, valamint a fertőzöttséggel együtt járó korlátozások indirekt hatásának következtében sokkal nagyobb a kedvezőtlen betegségkimenetel veszélye, mind a szomatikus, mind a pszichés szövődmények szempontjából. Ráadásul a járvány következtében beszúkült a pszichiátriai ellátórendszer kapacitása, és romlanak a segítségnyújtás lehetőségei [22], s ezek szintén hozzájárulhatnak a mentális alapbetegség relapsusához $[5,19]$. Éppen ezért a mentális zavarban szenvedők esetében speciális segítő beavatkozások szükségesek az állapotromlás és a társuló szövődmények (például öngyilkos magatartás) megelőzésére [37]. Ezek között természetesen az a legfontosabb, hogy a korlátozások ellenére is biztosítsuk számukra a rendszeres pszichiátriai kezelést és gondozást. Ebben egyre nagyobb szerepet kapnak az online, telepszichiátriai módszerek $[22,25$, 36]. Itt kell megemlíteni, hogy a mentális betegségben szenvedők esetében különösen fontos az adekvát és személyre szabott információközlés a fertőzés megelőzésének lehetőségeiről és a fertőzés kockázatairól, valamint az egészséges életmód jelentőségéről és összetevőiről (táplálkozás, testmozgás, napirend stb.) [38].

Az idôs populáció speciális helyzete is figyelmet érdemel, akik talán a leginkább veszélyeztetettek a szomatikus és pszichológiai következmények szempontjából [5, $12,13,19]$. A pandémia miatti szorongás és aggodalom miatt különösen nagy szükségük lenne a szociális és érzelmi támogatásra, miközben a megfertőződés kockázatának csökkentése érdekében elengedhetetlen a szociális távolságtartás [19]. Emiatt körükben is egyre gyakoribbá válhatnak a különböző pszichiátriai megbetegedések, melyek - különös tekintettel a depressziós hangulatzavarra - jelentősen növelik az öngyilkossági rizikót [39]. Az idős populáció esetében különösen fontosnak tűnik olyan suicidogen tényezők szerepe, mint amilyen az öszszetartozás hiánya és annak érzése, hogy terhet jelentenek hozzátartozóik és a tágabb közösség számára [40]. Érdekes módon az idősek egy része sokkal jobban viseli a korlátozásokat, és kevésbé jelentkeznek náluk a pszichológiai distressz következményei [36]. Ez fóleg azokra volt jellemző, akik olyan tulajdonságokkal bírtak, mint a fejlettebb érzelemszabályozás és megküzdőmechanizmusok, a resilientia, a bölcsesség, az empátia és az együttérzés, valamint lakóotthonban éltek, így kevésbé hatott rájuk a szociális izoláció. A hatékony stresszoldást biztosító faktorok ismerete kiemelt fontossággal bír az idősek számára nyújtott pszichológiai segítségnyújtás megtervezése szempontjából [41]. A kognitív hanyatlással küzdő idősek speciális rizikócsoportot jelentenek [5]. 
Körükben a járványhoz kapcsolódóan a dementiához társuló tünetek (szorongás, depresszió, alvászavar, irritabilitás és más viselkedészavarok) romlását észlelték, ami jelentősen növelte a gondozók terheit [42].

$\mathrm{Az}$ idősek mellett a fiatalok életét is alapvetően megváltoztatták a korlátozások, hiszen az online oktatásra való áttérés nemcsak nehezíti a tanulást, de fokozhatja a képzési előmenetellel kapcsolatos aggodalmakat [13, 38], ráadásul jelentősen beszúkíti a kortárs kapcsolatokat is, ami csökkenti a szociális támogatás esélyét [28]. Ezt egy francia felmérés eredményei is igazolták, melyek szerint a karanténban lévő egyetemi hallgatók jelentős arányban számoltak be súlyos pszichológiai distresszről, szorongásos-depressziós tünetekról és suicid intenciókról [43]. Ennek hátterében a hangulati homeosztázis önszabályozásának zavarát igazolták, mely különösen kifejezett volt a pszichiátriai betegségben szenvedók esetében. Ennek alapján körvonalazódott, hogy az érzelmi szabályozást javító módszerek elsajátítása fontos szereppel bír a mentálhigiénés prevencióban [44].

Az egyik legmagasabb suicidiumrizikóval bíró csoportot a vírusfertőzés szövődményeitől szenvedőket ellátó egészségügyi személyzet képezi, hiszen a súlyos vagy akár életveszélyes állapotban lévő fertőzöttek ellátása korábban szinte elképzelhetetlen fizikai és érzelmi megterhelést jelent [5, 13, 19, 20, 45]. Ráadásul sokszor nem állnak rendelkezésükre még a szükséges krízisoldást és tehermentesítést biztosító mentálhigiénés támogató szolgálatok sem. A segítségnyújtásra pedig óriási szükség van, hiszen az egészségügyi dolgozók között különösen magas a szorongásos-depressziós tünetek és a kiégés előfordulása. Egy széles körü metaanalízis adatai szerint a fertőzöttek ellátásában közremúködő egészségügyi dolgozók közel negyede szenved szorongásos vagy depreszsziós tünetektől, közel 40\%-uknál pedig alvászavar jelentkezett. A negatív pszichés következmények szempontjából a nővérek számítanak a legveszélyeztetettebbnek [46]. Gyakran tapasztalható az ellátásban részt vevő egészségügyi dolgozókkal kapcsolatban a stigmatizáció [12] és az ebből fakadó elutasító magatartás a környezetük részéről, ami szintén megnehezíti, hogy megfelelő érzelmi támogatást kaphassanak [5]. Pedig az egészségügyi személyzet problémáinak gyors megoldása különösen fontos, hiszen munkavégzésük hatékonyságának megörzése vagy helyreállítása alapvető jelentőségú a páciensek kezelésében és a járvány következményeinek leküzdésében.

Kiemelésre érdemes a tünetmentes fertözöttek és a fertőzöttekkel kapcsolatban álló kontaktszemélyek - egyre növekvő számú - populációja is, hiszen őket érinti a legjobban a megbetegedéstől való állandó rettegés és a tünetekkel való túlzott foglalkozás, ami komoly rizikót jelent a mentális betegségek kialakulása szempontjából. Különösen veszélyeztetettek azok, akik a vírusfertőzés következtében elvesztették hozzátartozójukat [2, 13]. Állapotukat tovább ronthatják a fertőzésveszély miatt alkalmazott korlátozások, melyek jelentősen megnehezítik azt is, hogy az érintettek megfelelő segítséget kapjanak. Egyre több adat bizonyítja, hogy a karanténban való tartózkodás vírusfertőzés nélkül is tovább súlyosbíthatja a negatív pszichés következményeket, melyek akár hoszszabb ideig fennállhatnak [25]. Ezek között a szorongás érzelmi és vegetatív tüneteinek fokozódásáról, a poszttraumás stressz tüneteiről, zavartságról és indulatkitörésről egyaránt beszámoltak [47]. Ennek hátterében a karanténban való tartózkodás elhúzódása, a megfertőződéstől való félelem, az alulinformáltság, a megfelelő érzelmi és szociális támogatás hiánya, a kényszerú bezártság következtében kialakuló unalom és frusztráció, az anyagi-egzisztenciális problémák felerôsödése és az esetleges fertőzéssel kapcsolatos stigmatizáció egyaránt szerepet játszhat [22]. A fenti tényezők mellett ki kell emelni a napi ritmus felborulását, az alvásminőség romlását és az alulinformáltságból eredő információéhséget is, mely gyakran vezet hírfüggőséghez. A fentiek arra hívják fel a figyelmet, hogy nagyon pontosan meg kell határozni a karanténhelyzet pontos kritériumait és ellátási protokollját, annak érdekében, hogy a korlátozások csak a legszükségesebb időtartamban kerüljenek alkalmazásra, és az egyének a számukra leginkább megfelelő támogatást kapják [13]. Nagyon fontos szerephez jut a családi és közösségi támogatás is [47]. Fontos hangsúlyozni a karanténban lévők altruista magatartását, hiszen ők jelentôs áldozatot hoznak annak érdekében, hogy a közösség más tagjai egészségesek maradhassanak [48]. A kutatók arra is felhívják a figyelmet, hogy a karantén feloldása sem oldja meg az összes problémát, mivel gyakran tapasztalható a karantén feloldását követő („visszatérési”) szorongásos reakció, mely megnehezítheti a hétköznapi életbe való visszailleszkedést [49].

A családok kényszerü bezártsága nemcsak a megszokott életritmus megváltozását és a családi szerepek felbomlását okozhatja, de felerősítheti a családi konfliktusokat, valamint a családon belüli erőszak és a gyermekbántalmazás előfordulásának gyakoriságát is növelheti $[5,13,20]$. Ezen tényezők összességében jelentős mértékben hozzájárulhatnak a traumatizált családtagok akut vagy hosszú távú suicid veszélyeztetettségének növekedéséhez [22]. A család izolált helyzete tehát a diszfunkcionális folyamatok felerősödését idézheti elő, miközben ilyenkor a külső segítség igénybevételének lehetősége is jelentősen beszúkül.

A pandémia közvetett negatív hatásai között kell megemlíteni a gazdasági válságot, mely az előrejelzések szerint akár súlyosabb lehet, mint a 2008. évi krízis. Bár a negatív gazdasági következmények a népesség széles körét érintik, ezek a folyamatok különösen kedvezőtlenül hatnak a hátrányos helyzetü, eleve rossz szociális körülmények között élőkre [12]. A gazdasági-financiális válság a legtöbbször számos olyan kedvezőtlen hatással jár (elbocsátások, munkanélküliség, anyagi és egzisztenciális problémák stb.), melyek az öngyilkossági magatartás rizikófaktorait jelentik, így a pandémiát követően a gazdasági helyzet elhúzódó romlásával összefüggésben a men- 
tális betegségek és a suicid viselkedés gyakoribbá válása prognosztizálható [19].

Napjainkban a pandémiával kapcsolatos információs robbanásnak lehetünk szem- és fülttanúi. A WHO által találóan infodémiának nevezett információáramlásban a médiumok legkülönbözőbb formái - a hírportáloktól kezdve a közösségi médiáig - ontják a híreket. Az adekvát és hasznos információkon túl gyakoriak az álhírek és a rémhírek, sok esetben jellemző a félelemkeltő és a szenzációhajhász stílus. Mivel a járvány okozta fenyegetettség következtében jelentősen megnőtt a hírolvasás gyakorisága, az ellenőrizetlen és kaotikus információáradat tovább növeli a szorongást, és ez a distressz és a médiahasználat fokozódásának egymást erősítő ördögi körét képezi. Közismert, hogy a járvány negatív következményeit túlhangsúlyozó, szenzációkeltő, stigmatizáló és katasztrofizáló médiaközlések nemcsak fokozzák az aggodalmakat és a szorongást, de akár suicidiumot is provokálhatnak [22].

\section{Általános és célzott prevenciós lehetőségek}

Egy ilyen világméretú válsághelyzetben sokszor megfigyelhető, hogy a közösség tagjai összefognak a bajban, a szociális kohézió erôsödése pedig protektív szereppel bírhat a negatív pszichológiai következmények enyhítése szempontjából [22, 25]. Sokat segíthetnek a modern infokommunikációs technikák, melyek a különböző virtuális platformok, online kapcsolati formák és közösségi hálózatok révén járulnak hozzá a szociális kapcsolatok fenntartásához akkor is, amikor a fertőzésveszélyt jelentő találkozásokra nincs lehetőség [1, 19, 20]. A különböző mentálhigiénés prevenciós módszerek (mint például az adekvát stresszoldás és a hatékonyabb érzelemkezelés) tudatos alkalmazásával [47] még a karantén jelentette kényszerü bezártságnak is lehetnek előnyei. Kiszakadva a hétköznapok taposómalmából, a család tagjainak több ideje lehet egymásra és saját magukra is. A látszólag beszúkült életkörülmények között egészségesebb és stresszmentesebb életmód alakítható ki. A napi hajsza helyett jóval több lehetőség nyílik aktív kikapcsolódásra, pihentetőbb alvásra vagy akár meditációra és elmélkedésre, intenzívebb fizikális aktivitásra és egészségesebb táplálkozásra. A passzív (jóga, meditáció) és aktív (éneklés, online kommunikáció, testmozgás) módszerek egyaránt hatékonynak bizonyultak a szorongásos-depressziós tünetek megelözésében $[28,39]$.

Szerencsére ma már számos, evidenciákon alapuló népegészségügyi módszer ismert, melyeknek a jelenlegi helyzetre való adaptációja esélyt nyújt a járvány következtében kialakuló mentális problémák enyhítésére és a suicid viselkedés megelőzésére [22]. Elsőként az általános prevenciós beavatkozásokat kell említeni. Idetartozik a mentálhigiénés, pszichiátriai és addiktológiai ellátórendszerek elérhetőségének és hatékonyságának növelése, a szociális és egzisztenciális segítséget nyújtó közösségi szervezetek és a krízisintervenciós (telefon)szolgálatok fejlesztése, valamint a financiális problémák kezelését és a munkanélküliség csökkentését célzó munkapiaci programok kidolgozása [12, 20-24, 34]. Mivel a pandémia mentálhigiénés következményeinek elhúzódó jelentkezése várható, olyan, nemzeti öngyilkosság-megelőző stratégia kidolgozása látszik szükségesnek, melyben az általános suicidiumprevenciós alapelvek mellett a regionális jellemzők is szerepet kapnak [16, 20, 22]. Az öngyilkosságokkal foglalkozó jövőbeli kutatások fontos területét képezi a prevenciós és terápiás módszerek alkalmazhatóságának folyamatos vizsgálata ezen módszerek eredményességének növelésére [2, 22, 25].

A pandémiához kapcsolódó öngyilkos viselkedés sikeres megelőzésében is a komplex módszerek alkalmazása szükséges, az univerzális, a szelektív és a célzott megközelítésnek egyaránt szerepet kell kapnia [2, 20, 22, 25].

Az univerzális megközelitésben nagy jelentőségük van az általános mentálhigiénés és egészségprevenciós módszereknek. Idetartoznak például a szorongás és a félelem csökkentésére alkalmazott hatékony és egyszerü stresszoldó technikák, melyeknek természetesen indirekt suicidiumprevenciós hatásuk is van [22]. Nagy szerepük van a hagyományos és a szociális média által közvetített egészségpromóciós alapelveknek is $[12,25]$. Az öngyilkosság-megelőzés szempontjából nagy jelentőséggel bír az öngyilkossággal kapcsolatos médiaközléseket szabályozó irányelvek alkalmazása $[12,16,19,20,22,24]$. Így egyrészt megelőzhető a suicid modellkövetés negatív hatása, másrészt a segítségnyújtás lehetőségeiről való tájékoztatás révén a suicid krízisben lévők időben megfelelő ellátást kaphatnak [50]. A járvány következményeivel és kezelésének lehetőségeivel foglalkozó, adekvát és hiteles információközlés mellett fontos a beszúkült és megváltozott életkörülményekhez társuló problémák megoldási lehetőségeinek bemutatása is. Ez elősegíti a pszichológiai distressz oldását, mely a saját élet feletti kontroll elvesztéséhez és a szociális izolációhoz társul. A korlátozások következményeinek enyhítését célzó életmódbeli változások bemutatása is elengedhetetlen. Ennek elemei közé tartozik a meghatározott napirend kialakítása, a túlzott hírolvasás vagy hírfüggőség kerülése, a rendszeres fizikai aktivitás és a szabadtéri tevékenységek, valamint az egyénre szabott stresszkezelő módszerek alkalmazása is [25].

Nemcsak a járvány idején, de az akut időszak lezajlását követően is kiemelt jelentőségű a mentálhigiénés problémák folyamatos szürése és a rizikófaktorok pontos értékelése, hiszen csak így nyílik lehetőség a veszélyeztető tünetek korai felismerésére és kezelésére [22, 25]. Fontos szerephez jutnak a különböző közösségi, szociális és mentálhigiénés szervezetek, melyek azok számára is biztosíthatják a megfelelő érzelmi támogatást, akik egyedül élnek, és nem számíthatnak a családjukra vagy a környezetükben élőkre. Kiemelt jelentőséggel bírnak a mindenki számára elérhető, azonnali segítséget nyújtó öngyilkosság-megelőző telefonszolgálatok is [12]. A kliensekkel közvetlen kapcsolatban lévő segítőknek (szociális mun- 
kások, házigondozók és ápolók, háziorvosok stb.) kivételes lehetőségük nyílik arra, hogy a kapcsolattartás során folyamatosan követni tudják klienseik lelkiállapotát [39]. A számukra szervezett speciális képzések növelik annak esélyét, hogy felismerjék a suicid veszély figyelmeztető előjeleit [12]. Így a súlyosbodó depresszió, szorongás és más pszichés tünetek, krízisjegyek vagy akár suicid gondolatok észlelése esetén gondoskodni tudnak arról, hogy a pszichés tünetekkel küzdő vagy krízisben lévő páciens a lehető legszakszerúbb ellátásban részesüljön [22].

Az emelkedett suicid rizikóval bíró csoportok esetében a szelektín módszerek alkalmazása indokolt $[22,25]$. A mentális zavarban szenvedők esetében fontos az ellátás folyamatosságának biztosítása és a páciens igényeihez illesztett módszerek alkalmazása. Hangsúlyozzuk, hogy a többi veszélyeztetett csoport (egészségügyi dolgozók, idősek és fiatalok, hátrányos szocioökonómiai helyzetben lévők stb.) esetében is fontos suicidiumprevenciós jelentősége van a mentálhigiénés problémák minél korábbi felismerésének és ezek hatékony kezelésének [40].

A különösen magas suicid rizikóval rendelkezők csoportja (mint például a suicid kísérletet elkövetők, a lélektani krízisben lévők) esetében elengedhetetlen a célzott beavatkozás, a krízisintervenciós technikák azonnali alkalmazása és a háttérben lévő mentális zavarok felismerése és kezelése, szükség esetén a páciens gondozásba vétele $[22,25]$. Figyelmet kell fordítani a tragikus eseményeket átéltek poszttraumás tüneteinek, valamint a fertőzésben elhunytak gyászoló hozzátartozóinak hatékony kezelésére. A mentális zavarok kezelésében napjainkban már egyre inkább szerepet kapnak a modern telepszichiátriai és telepszichoterápiás lehetőségek is [39, 40], melyek a személyes kontaktushoz hasonló hatékonysággal múködnek, így a járvány okozta korlátozások esetén is eredményesen alkalmazhatók [19].

\section{Következtetések}

A suicid viselkedés multifaktoriális háttérrel bír, mely számos intrapszichés, interperszonális és környezeti-kulturális tényező bonyolult összjátékának következtében alakul ki. A pandémiához és elhúzódó hatásaihoz kapcsolódó suicid rizikó hátterében is számos neurobiológiai, pszichológiai, szociális és gazdasági-társadalmi tényező szerepe igazolódott, melyek egymást erősítő hatásuk révén a suicid ráták növekedését okozhatják [2, 22]. Az egészségügyi és közösségi mentálhigiénés és segítő szolgálatoknak minden lehetőséget meg kell ragadniuk a pandémia okozta válsághelyzet negatív következményeinek mérséklésére és a pozitív hatások facilitálására [37]. A suicid viselkedés megelőzésében azonban ezen ellátórendszerek mellett a döntéshozó politikai-kormányzati szerveknek, a közösségi támogató szervezeteknek és a média munkatársainak is fontos részt kell vállalniuk [22]. Az egészségügy túlterhelése miatt kiemelt jelentőséggel bírnak a különböző, közösségi alapú suicidiumprevenciós módszerek is. A rövid, strukturált, akár személyesen, akár online is alkalmazható módszerek segítségével a közösség tagjaival kapcsolatban álló háziorvosok, védőnők, mentálhigiénikusok vagy szociális munkások is könnyebben tudják azonosítani a suicid veszélyben lévőket, és hatékonyan tudják alkalmazni az életmentő krízisintervenciós technikákat [22].

A vizsgálatok arra utalnak, hogy a pandémia következtében kialakuló krónikus pszichológiai distressz, a mentális zavarok és a suicid viselkedés egyre fontosabb közegészségügyi problémát jelentenek. Bár jelenleg a vírusfertőzöttek gyógyítása és a járvány akut következményeinek mérséklése áll az egészségügyi ellátás középpontjában, mindannyiunknak fel kell készülnünk a hoszszú távú következményekre is. A pandémia várható negatív mentálhigiénés hatásainak megelőzésére és enyhítésére általános és specifikus, lokális szinten is alkalmazható hatékony stratégiák kidolgozása és alkalmazása szükséges [22, 24]. Az egyéni, közösségi és társadalmi szinten alkalmazott prevenciós módszerek segítségével megelőzhető a súlyosabb mentálhigiénés problémák járványszerü terjedésének (a „pszichodémiának”) a kialakulása. Ezek korai felismerésével és adekvát kezelésével nemcsak pácienseink gyötrelmeit tudjuk enyhíteni, de a sokszor életveszélyes szövődmények - mint például a suicid viselkedésformák - is megelőzhetővé válnak. A krízisparadigma értelmében a válsághelyzet eredményes megoldása nemcsak a pandémia előtti helyzetbe való visszatérést eredményezi, de esélyt nyújt az egyének és a közösségek fejlődésére is.

Anyagi támogatás: A közlemény megírása anyagi támogatásban nem részesült.

A szerző a cikk végleges változatát elolvasta és jóváhagyta.

Érdekeltségek: A szerzőnek nincsenek érdekeltségei.

\section{Irodalom}

[1] Galea S, Merchant RM, Lurie N. The mental health consequences of COVID-19 and physical distancing: the need for prevention and early intervention. JAMA Intern Med. 2020; 180: 817-818.

[2] Sher L. The impact of the COVID-19 pandemic on suicide rates. QJM Int J Med. 2020; 113: 707-712.

[3] González-Sanguino C, Ausín B, Castellanos MÁ, et al. Mental health consequences of the coronavirus 2020 pandemic (COVID-19) in Spain. A longitudinal study. Front Psychiatry 2020; 11: 565474.

[4] Postolache TT, Benros ME, Brenner LA. Targetable biological mechanisms implicated in emergent psychiatric conditions associated with SARS-COV-2 infection. JAMA Psychiatry $2020 \mathrm{Jul}$ 31. Doi: 10.1001/jamapsychiatry.2020.2795. [Epub ahead of print]

[5] Lazáry J. Acute effects of the first period of COVID-19 pandemic on mental state. [A COVID-19 pandémia akut hatásai a pszichés állapotra a járvány első szakaszában.] Neuropsychopharmacol Hung. 2020; 22: 172-177. [Hungarian] 
[6] Rogers JP, Chesney E, Oliver D, et al. Psychiatric and neuropsychiatric presentations associated with severe coronavirus infections: a systematic review and meta-analysis with comparison to the COVID-19 pandemic. Lancet Psychiatry 2020; 7: 611-627.

[7] Kennedy M, Helfand BK, Gou RY, et al. Delirium in older patients with COVID-19 presenting to the Emergency Department. JAMA Netw Open 2020; 3: e2029540.

[8] Rozzini R, Bianchetti A, Mazzeo F, et al. Delirium: clinical presentation and outcomes in older COVID-19 patients. Front Psychiatry 2020; 11: 586686.

[9] Panariello F, Cellini L, Speciani M, et al. How does SARS COV-2 affect the central nervous system? A working hypothesis. Front Psychiatry 2020; 11: 582345.

[10] Janiri D, Kotzalidis GD, Giuseppin G, et al. Psychological distress after COVID-19 recovery: reciprocal effects with temperament and emotional dysregulation. An exploratory study of patients over 60 years of age assessed in a post-acute care service. Front Psychiatry 2020; 11: 590135.

[11] Taquet M, Luciano S, Geddes JR, et al. Bidirectional associations between COVID-19 and psychiatric disorder: retrospective cohort studies of 62354 COVID-19 cases in the USA. Lancet Psychiatry 2021; 8: 130-140. [Published online November 9, 2020] [Erratum: Lancet Psychiatry 2021; 8: el.]

[12] Banerjee D, Kosagisharaf JR, Sathyanarayana Rao TS. 'The dual pandemic' of suicide and COVID-19: a biopsychosocial narrative of risks and prevention. Psychiatry Res. 2021; 295: 113577.

[13] Zalsman G, Stanley B, Szántó K, et al. Suicide in the time of COVID-19: review and recommendations. Arch Suicide Res. 2020; 24 : 477-482

[14] Asmundson GJ, Taylor S. Coronaphobia: fear and the 2019nCoV outbreak. J Anxiety Disord. 2020; 70: 102196.

[15] Leske S, Kõlves K, Crompton D, et al. Real-time suicide mortality data from police reports in Queensland, Australia, during the COVID-19 pandemic: an interrupted time-series analysis. Lancet Psychiatry 2021; 8: 58-63.

[16] John A, Pirkis J, Gunnell D, et al. Trends in suicide during the COVID-19 pandemic. BMJ 2020; 371: m4352.

[17] Qin P, Mehlum L. National observation of death by suicide in the first 3 months under COVID-19 pandemic. Acta Psychiatr Scand. 2021; 143: 92-93.

[18] Hawton K, Casey D, Bale E, et al. Self-harm during the early period of the COVID-19 pandemic in England: comparative trend analysis of hospital presentations. medRxiv preprint doi: https://doi.org/10.1101/2020.11.25.20238030; this version posted November 29, 2020.

[19] Reger MA, Stanley IH, Joiner TE. Suicide mortality and coronavirus disease 2019. A perfect storm? JAMA Psychiatry 2020; 77 : 1093-1094.

[20] Gunnell D, Appleby L, Arensman E, et al. COVID-19 suicide prevention research collaboration. Suicide risk and prevention during the COVID-19 pandemic. Lancet Psychatry 2020; 7: $468-471$.

[21] McIntyre RS, Lee Y. Preventing suicide in the context of the COVID-19 pandemic. World Psychiatry 2020; 19: 250-251.

[22] Wasserman D, Iosue $M$, Wuestefeld A, et al. Adaptation of evi dence-based suicide prevention strategies during and after the COVID-19 pandemic. World Psychiatry 2020; 19: 294-306.

[23] Bastiampillai T, Allison S, Looi JC, et al. The COVID-19 pandemic and epidemiologic insights from recession-related suicide mortality. Mol Psychiatry 2020; 25: 3445-3447.

[24] Moutier C. Suicide prevention in the COVID-19 era: transforming threat into opportunity. JAMA Psychiatry 2020 Oct 16. Doi: 10.1001/jamapsychiatry.2020.3746. [Epub ahead of print]

[25] Niederkrotenthaler T, Gunnell D, Arensman E, et al., International COVID-19 Suicide Prevention Research Collaboration. Suicide research, prevention, and COVID-19. Crisis 2020; 41: 321-330.
[26] Gratz KL, Tull MT, Richmond JR, et al. Thwarted belongingness and perceived burdensomeness explain the associations of COVID-19 social and economic consequences to suicide risk. Suicide Life Threat Behav. 2020; 50: 1140-1148.

[27] Wang C, Pan R, Wan X, et al. Immediate psychological responses and associated factors during the initial stage of the 2019 coronavirus disease (COVID-19) epidemic among the general population in China. Int J Environ Res Public Health 2020; 17: 1729.

[28] Ge F, Wan M, Zheng A, et al. How to deal with the negative psychological impact of COVID-19 for people who pay attention to anxiety and depression. Prec Clin Med. 2020; 3: 161168.

[29] Mazza C, Ricci E, Biondi S, et al. A nationwide survey of psychological distress among Italian people during the COVID-19 pandemic: immediate psychological responses and associated factors. Int J Environ Res Public Health 2020; 17: 3165.

[30] Winkler P, Formanek T, Mlada K, et al. Increase in prevalence of current mental disorders in the context of COVID-19: analysis of repeated nationwide cross-sectional surveys. Epidemiol Psychiatr Sci. 2020; 29: el73.

[31] Kantor BN, Kantor J. Mental health outcomes and associations during the COVID-19 pandemic: a cross-sectional populationbased study in the United States. Front Psychiatry 2020; 11 : 569083.

[32] Holingue C, Kalb LG, Riehm KE, et al. Mental distress in the United States at the beginning of the COVID-19 pandemic. Am J Public Health 2020; 110: 1628-1634.

[33] Ettman CK, Abdalla SM, Cohen GH, et al. Prevalence of depression symptoms in US adults before and during the COVID-19 pandemic. JAMA Netw Open 2020; 3: e2019686.

[34] Czeisler MÉ, Lane RI, Petrosky E, et al. Mental health, substance use, and suicidal ideation during the COVID-19 pandemic: United States, June 24-30, 2020. Morb Mortal Wkly Rep. 2020; 69: 1049-1057.

[35] Serafini G, Rihmer Z, Amerio A, et al. COVID-19 infection and mental disorders: a call for action to enhance protection and break down barriers. Psychiatr Hung. 2020; 35: 245-246.

[36] Pogány L, Horváth A, Slezák A, et al. The first lockdown due to COVID-19 pandemic from the psychiatric patients' perspective: an ambulatory care client experience survey. [A COVID-19járvány miatt elrendelt első veszélyhelyzet a pszichiátriai betegek szemszögéből: gondozói felmérés.] Neuropsychopharmacol Hung. 2020; 22: 144-153. [Hungarian]

[37] Kulig B, Erdélyi-Hamza B, Elek LP, et al. Effects of COVID-19 on psychological well-being, lifestyle and attitudes towards the origins of the pandemic in psychiatric patients and mentally healthy subjects: first Hungarian descriptive results from a large international online study. [A COVID-19-pandémia hatása a pszichológiai jóllétre, az életmódra és a járvány eredetével kapcsolatos attitúdökre pszichiátriai betegséggel élő és egészséges személyekben: egy nagy nemzetközi vizsgálat első magyarországi adatai.] Neuropsychopharmacol Hung. 2020; 22: 154-165. [Hungarian]

[38] McGinty EE, Presskreischer R, Han H, et al. Psychological distress and loneliness reported by US adults in 2018 and April 2020. JAMA 2020; 324: 93-94.

[39] Wand AP, Zhong BL, Chiu HF, et al. COVID-19: the implications for suicide in older adults. Int Psychogeriatr. 2020; 32: 1225-1230.

[40] Sheffler JL, Joiner TE, Sachs-Ericsson NJ. The interpersonal and psychological impacts of COVID-19 on risk for late-life suicide. Gerontologist 2021; 61: 23-29.

[41] Vahia IV, Jeste DV, Reynolds CF 3rd. Older adults and the mental health effects of COVID-19. JAMA 2020; 324: 2253-2254.

[42] Penteado CT, Loureiro JC, Pais MV, et al. Mental health status of psychogeriatric patients during the 2019 new coronavirus disease (COVID-19) pandemic and effects on caregiver burden. Front Psychiatry 2020; 11: 578672. 
[43] Wathelet M, Duhem S, Vaiva G, et al. Factors associated with mental health disorders among university students in France confined during the COVID-19 pandemic. JAMA Netw Open 2020; 3: e2025591.

[44] Taquet M, Quoidbach J, Fried EI, et al. Mood homeostasis before and during the coronavirus disease 2019 (COVID-19) lockdown among students in the Netherlands. JAMA Psychiatry 2021; 78: 110-112.

[45] Reger MA, Piccirillo ML, Buchman-Schmitt JM. COVID-19, mental health, and suicide risk among health care workers: looking beyond the crisis. J Clin Psychiatry 2020; 81(5): $20 \operatorname{com} 13381$

[46] Pappa S, Ntella V, Giannakas T, et al. Corrigendum to "Prevalence of depression, anxiety, and insomnia among healthcare workers during the COVID-19 pandemic: a systematic review and meta-analysis" [Brain Behav. Immun. 88 (2020) 901-907]. Brain Behav Immun. 2020 Dec 9. Available from: https://doi. org/10.1016/j.bbi.2020.11.023
[47] Mariani R, Renzi A, Di Trani, et al. The impact of coping strategies and perceived family support on depressive and anxious symptomatology during the coronavirus pandemic (COVID-19) lockdown. Front Psychiatry 2020; 11: 587724.

[48] Brooks SK, Webster RK, Smith LE, et al. The psychological impact of quarantine and how to reduce it: rapid review of the evidence. Lancet 2020; 395: 912-920.

[49] Watson J. COVID-19's psychological impact gets a name. Medscape Med News, September 29, 2020. Available from: https:// www.medscape.com/viewarticle/938253\#vp_2

[50] Hawton K, Marzano L, Fraser L, et al. Reporting on suicidal behaviour and COVID-19 - need for caution. Lancet Psychiatry 2021; 8: 15-17.

(Osváth Péter dr., Pécs, Rét u. 2., 7623 e-mail: osvath.peter@pte.hu)

\section{"Lupus pilum mutat, non mentem." (A farkas csak a szőrét váltja, nem a gonosz szándékát.)}

A cikk a Creative Commons Attribution 4.0 International License (https://creativecommons.org/licenses/by/4.0/) feltételei szerint publikált Open Access közlemény, melynek szellemében a cikk bármilyen médiumban szabadon felhasználható, megosztható és újraközölhetö, feltéve, hogy az eredeti szerző és a közlés helye, illetve a CC License linkje és az esetlegesen végrehajtott módosítások feltüntetésre kerülnek. (SID_1) 